Available online at http://jurnal.stmikroyal.ac.id/index.php/jurteksi

\title{
PEMETAAN SISWA BERPRESTASI MENGGUNAKAN METODE K-MEANS CLUSTERING
}

\author{
Fitri Larasati Sibuea ${ }^{1}, \&$ Andy Sapta ${ }^{2}$ \\ ${ }^{1,2}$ Sistem Informasi, STMIK Royal \\ email: ${ }^{1}$ bukmus.inaction@gmail.com, ${ }^{2}$ saptaandy@gmail.com
}

\begin{abstract}
The high level of student success and the low level of student failure is a quality of the education world. The world of education is currently required to have the ability to compete by utilizing all resources owned. In addition to facilities, infrastructure and human resources, information systems are one of the resources that can be used to improve competency skills. Data mining is a process of data analysis to find a dataset of data set. Data mining is able to analyze large amounts of data into information that has meaning for decision supporters. One process of data mining is clustring. Attributes used in the grouping of student achievement are Name, Extracurricular, Value which include Task Value, Uts Value, Value of Uses, total absenteeism, and Attitude value. The case study of 20 students with distance calculation using manhattan distance, chbychep distance and euclidian distance yielded $67 \%$ accuracy.
\end{abstract}

Keywords: data mining, clustering, k-means, student achievement

\begin{abstract}
Abstrak: Tingginya tingkat keberhasilan siswa dan rendahnya tingkat kegagalan siswa merupakan cemin kualitas dunia pendidikan.Dunia pendidikan saat ini dituntut untuk memiliki kemampuan bersaing dengan memanfaatkan semua sumber daya yang dimiliki. Selain sumber daya sarana, prasarana dan manusia, sistem informasi merupakan salah satu sumber daya yang dapat digunakan untuk meningkatkan kemampuan barsaing. Data mining merupakan proses analisa data untuk menemukan suatu pola dara kumpulan data. Data mining mampu menganalisa jumlah data yang besar menjadi informasi yang mempunyai arti bagi pendukung keputusan. Salah satu proses data mining adalah clustring. Atribut yang digunakan dalam pengelompokan prestasi siswa adalah Nama, Ekstrakulikuler, Nilai yang meliputi Nilai Tugas, Nilai Uts, Nilai Uas, jumlah ketidak hadiran siswa (absensi), dan Nilai sikap. Studi kasus pada 20 siswa dengan perhitungan jarak menggunakan manhattan distance, chbychep distance dan euclidian distance menghasilkan akurasi sebesar $67 \%$.
\end{abstract}

Kata kunci: data mining, clustering, $k$-means, prestasi siswa

\section{PENDAHULUAN}

Dewasa ini pengolahan data elektronika telah menjadi kebutuhan yang sangat utama. Perkembangan pesat dalam teknologi informasi yang menjadikan semua informasi dapat disimpan dalam jaringan komputer telah membuat munculnya sistem basis data yang sangat besar. Dalam hitungan detik, data-data 
Available online at http://jurnal.stmikroyal.ac.id/index.php/jurteksi

dalam berbagai basis data akan senantiasa terbarukan, baik dikarenakan adanya update maupun penambahan data baru. Permasalahn yang kemudian muncul adalah bagaimana mengetahui informasi yang terdapat dalam basis data yang sangat besar.

Knowledge discovery in database (KDD) didefenisikan sebagai ekstraksi informasi potensial, implisit dan tidak dikenal dari sekumpulan data. Proses knowledge discovery melibatkan hasil dari proses data mining (proses mengekstrak kecenderungan pola suatu data), kemudia mengubah hasilnya secara akurat menjadi informasi yang mudah dipahami.

Ada beberapa macam pendekatan berbeda yang diklasifikasikan sebagai teknik pencarian informasi/pengetahuan dalam KDD. Ada pendekatan kuantitatif, seperti pendekatan probalistik and statistik. Beberapa pendekatan memanfaatkan teknik visualisasi, pendekatan klasifikasi seperti logika induktif, pencarian pola, dan analisis pohon keputusan. Pendekatan yang lain meliputi deviasi, analisis kecendrungan, algoritma genetik, jaringan syaraf tiruan dan pendekatan campuran dua atau lebih dari beberapa pendekatan yang ada.

Tingginya tingkat keberhasilan siswa dan rendahnya tingkat kegagalan siswa merupakan cermin kualitas dunia pendidikan. Dunia pendidikan saat ini dituntut untuk memiliki kemampuan bersaing dengan memanfaatkan semua sumber daya yang dimiliki. Selain sumber daya sarana, prasarana dan manusia. Sistem informasi dapat digunakan untuk meningkatkan kemampuan bersain. Sistem informasi dapat digunakan untuk menunjang kegiatan opersional seharihari sekaligus menunjang kegiatan pengambilan keputusan strategis.

Metode pengambilan keputusan konvensional yang ada, tidak dapat menangani data dalam jumlah yang sangat besar. Hal ini mendorong munculnya cabang ilmu baru untuk mengatasi masalah penggalian informasi yang penting dari data kumpulan data, yang disebut dengan data mining.

Secara umum penilaian prestasi siswa yaitu mata pelajaran baik teori dan praktek, penilaian ekstrakurikuler kehadiran dan ketidakhadiran siswa dan pada saat mengikuti ekstrakulikuler, yang dikategorikan dalam nilai pengetahuan, nilai keterampilan dan penilaan sikap. Evaluasi dan penilaian terhadap prestasi siswa dilakukan dengan memberi nilai oleh pengajar kepada semua siswa yang mengikuti pelajaran yang diajarkan dan ekstrakurikuler yang diikutinya.

Seiring dengan terus bertambahnya jumlah data siswa setiap tahun, maka jumlah data yang siswa yang terus meningkat sehingga penumpukan data yang belum diolah dengan optimal untuk menggali imformasi dan pengetahuan baru melalui pola-pola yang terbentuk dari penumpukan data tersebut. Jumlah data yang terus meningkat ini merupakan bebrapa teknik ataupun metode untuk mengolah nya menjadi sebuah informasi dan pengetahuan yang dapat digunakan sebagai bahan pertimbangan pendidik dalam proses pengambilan kebijakan dan keputusan juga sebagai peringatan dini (early warning) bagi siswa tertentu yang berdasarkan hasil pengelompokan prestasi rendah yang berpotensi terhadap ketidak lulusan siswa.

Beberapa penelitian yang telah dilakukan melakukan pemodelan mengenai pemodelan aturan dalam memprediksi akademik siswa, mengevaluasi kinerja akademik mahasiswa pada tahun ke-2 dan diklasifikasikan dalam kategori mahasiswa yang dapat lulus tepat waktu atau tidak, konsep pengclasteran dengan pola data yang sudah diatur, tehnik cluster membuat pengelompokan data iklim tropis di samudra hindia bagian utara.

\section{Data Mining}

Data mining merupakan salah satu disiplin ilmu yang digunakan untuk menentukan suatu informasi tertentu dalam sekumpulan data sebagai pen- 
Available online at http://jurnal.stmikroyal.ac.id/index.php/jurteksi

dukung pengambilan keputusan. Data mining juga sebagai salah satu proses untuk memproleh informasi yang memiliki nilai guna dari sekumpulan data (Tan, 2006).

Data Mining adalah suatu istilah yang digunakan untuk menguraikan penemuan pengetahuan didalam database. Data Mining adalah proses yang menggunkan teknik statistik, matematika, kecerdasan buatan dan machine learning untuk menginteraksi mengidentifikasi informasi yang bermanfaat dan pengetahuan yang terikat dari berbagai database besar( Kusrini, 2009).

Data Mining merupakan proses menemukan kolerasi baru yang bermanfaat, pola dan trend dengan manmbang sejumlah repositori data dalam jumlah besar, menggunakan teknologi pengenalan pola seperti statisik dan teknik matematika. Data Mining semakin menyebar dan berkembang dengan pesat belakngan ini karena kemampuannya dalam menambang pola bermanfaat dan trend dari basis data yang sudah ada. Perusahaan-perusahaan telah menghabiskan dana milyaran untuk mengumpulkan data dalam jumlah megabytes atau terabytes tapi tidak mendapatkan keuntungan yang bernilai didalamnya, padahal didalamnya terbapat informasi yang berharga namun tersembunyi pada repositori data. (Larose, 2005)

Menurut Prastyo (2012), data mining terbagi menjadi beberapa kelompok yaitu sebagai berikut:

\section{Model Prediksi}

Pemodelan yang dapat melakukkan pemetaan dari setiap himpunan variabel ke setiap targetnya, kemudian menggunakan model tersebut untuk memberikan nilai target pada himpunan baru yang telah didapat.

2. Analisis Kelompok

Mengelompokkan sekumpulan data ke dalam kelompok (cluster) tertentu berdasarkan karakteristik yang sama pada masing-masing data.

3. Analisis Asosiasi
Menentukan pola yang menggambarkan kekuatan hubungan fitur dalam data.

4. Deteksi Anomaly

Pengamatan suatu data dari sekumpulan data yang secara signifikan memiliki karakteristik yang berbeda dari sisa data yang lain. (Larose, 2005)

Data mining telah dipakai diberbagai bidang seperti ilmu sains, bisnis dan industri, teknik, kesehatan, serta pertahanan dan keamanan. Menurut (Ayub, 2007) Ketersediaan data yang berlimpah yang dihasilkan dari penggunaan teknologi informasi dihampir semua bidang kehidupan, menimbulkan kebutuhan untuk dapat memanfaatkan informasi dan pengetahuan yang terkandung didalam limpahan data tersebut, yang kemudian melahirkan data mining. data mining merupakan proses untuk menemukan pengetahuan (knowledge discovery) yang ditambang dari sekumpulan data yang volumenya sangat besar.

\section{Algoritma K-Means}

K-Means merupakan suatu algoritma pengklasteran yang cukup sederhana yang mempartisi databest kedalam beberapa clasteran k.Algoritma cukup mudah untuk diimplementasikan dan dijalakan, relatif cepat, mudah disesuaikan dan banyak digunakan (Wu \& Kumar, 2009). Prinsip uatama dari teknik ini adalah menyusun $K$ buah partisi/pusat massa (centroid)/rata-rata (mean) dari sekupulan data. Algoritma K-Means dimulai dengan pembentukan partisi klaster diawal kemudian secara iteraktif partisi claster ini diperbaiki hingga tidak terjadi perubahan yang signifikan pada partisi claster (Written, 2011).

Langkah pertama algoritma $k$ means adalah menentukan jumlah cluster, padga penelitian ini ditetapkan 3 cluster, yang dipilih secara random. dengan variabel jumlah ekstrakulikuler, nilai ratarata, Absen. 
Available online at http://jurnal.stmikroyal.ac.id/index.php/jurteksi

Ada banyak metode yang dapat digunakan dalam pengelompokan contohnya metode K-means. Pengelompokan yang dapat digunakan seperti pengelompokan non hierarki yang membagi data kedalam bentuk dua atau lebih kelompok. K-means merupakan metode analisis kelompok yang mengarah pada pembagian $N$ objek pengamatan kedalam K kelompok (cluster) dansetiap objek pengamatan dimiliki oleh suatu kelompok dengan rata-rata (mean) terdekat (Prasetyo, 2012).

Dalam menentukan nilai centroid untuk awal interasi, nilai awal centroid dilakukan secara acak. Sedangkan jika menentukan nilai centroid yang merupakan tahap dari iterasi, maka digunakan rumus sebagai berikut:

$$
\bar{v}_{t j}=\frac{1}{N_{i}} \sum_{k=0}^{N_{i}} x_{k j} .
$$

1. Menghitung jarak antara titik centroid dengan titik tiap objek.

$$
\mathrm{D}_{e}=\sqrt{\left(x_{i}-s_{i}\right)^{2}+\left(y_{i}-t_{i}\right)^{2}}
$$

2. Pengelompokan object untuk menentukan anggota cluster adalah dengan memperhitungkan jarak minimum objek.

3. Kembali ke tahap ke-2, lakukan perulangan hingga nilai centroid yang dihasilkan tetap dan anggota cluster tidak berpindah ke cluster lain.

Metode K-Means Clustering hanya bisa mengolah data dalam bentuk angka, maka untuk data yang berbentuk nominal harus diinisialisasikan terlebih dahulu ke dalam bentuk angka. Langkahnya adalah:

1. Urutkan data berdasarkan frekuensi kemunculannya.

2. Inisialisasikan data tersebut mulai dari data tertinggi dengan niali 1 . Kemudian data selanjutnya 2, 3 dan seterusnya.

Kelemahan K-Means:
1. Bila jumlah data tidak terlalu banyak, mudah untuk menetukan cluster awal.

2. Jumlah cluster, sebanyak $K$, harus ditentukan sebelum dilakukan perhitungan.

3. Tidak pernah mengetahui real cluster dengan menggunakan data yang sama, namun jika dimasukan dengan cara yang bebeda mungkin dapat memproduksi cluster yang berbeda jika jumlah datanya sedikit.

4. Tidak tahu kontribusi dari atribut dalam proses pengelompokan karena dianggap bahwa setiap atribut memiliki bobot yang sama.

\section{RapidMiner}

RapidMiner merupakan perangakat lunak yang bersifat terbuka (open source). RapidMiner adalah sebuah solusi untuk melakukan analisis terhadap data mining, text mining dan analisis prediksi. RapidMiner menggunakan berbagai teknik deskriptif dan prediksi dalam memberikan wawasan kepada pengguna sehingga dapat membuat keputusan yang paling baik. RapidMiner memiliki kurang lebih 500 operator data mining, termasuk operator untuk input, output, data preprocessing dan visualisasi. RapidMiner merupakan software yang berdiri sendiri untuk analisis data dan sebagai mesin data mining yang dapat diintegrasikan pada produknya sendiri. RapidMiner ditulis dengan munggunakan bahasa java sehingga dapat bekerja di semua sistem operasi.

\section{METODOLOGI}

Clustering merupakan salah satu teknik dari salah satu fungsionalitas data mining, algoritma clustering merupakan algoritma pengelompokan sejumlah data menjadi kelompok-kelompok data tertentu (cluster).

Setiap cluster memiliki centroid yang merupakan suatu besaran yang 
Available online at http://jurnal.stmikroyal.ac.id/index.php/jurteksi

dihitung dari rata-rata nilai tiap items dari suatu cluster dan juga memiliki medoid yang merupakan item yang letaknya paling tengah. Sementara jarak antar cluster didefenisikan dengan menggunkan beberapa metode-metode untuk menentukan cluster mana yang berdekatan. (Kusrini, 2009)

1. Single Link adalah jarak terkecil antara satu elemen cluster dalam suatu cluster dengan elemen dalam suatu cluster dengan elemen lain di cluster yang berbeda.

2. Complete Link adalah jarak terbesar antara satu elmen dalam suatu cluster dengan elemen lain dicluster yang berbeda.

3. Average adalah jarak rata-rata antara satu elemen dalam suatu cluster dengan elemen lain di cluster yang berbeda.

4. Centroid adalah jarak anatar centroid dari tiap cluster dengan centroidcluster lainnya.

5. Medoid adalah jarak antara medoid dari tiap cluster dengan medoid cluster lainya.

\section{HASIL DAN PEMBAHASAN}

Data yang diolah dalam penelitian ini merupakan sampel yang diambil dari data rapot peserta didik SMK Yapim Simpang Kawat kelas $\mathrm{X}$ AK2 tahun ajaran 2016/2017. Dataset siswa terdiri dari atribut data induk dan data rapot. Atribut yang dijadikan variable dalam algoritma ini di sederhanakan menjadi atribut yang terdiri dari NIS, Nama, Ekstrakulikuler, Nilai Tugas, Uts , Uas dan Jumlah ketidakhadiran. Data sampel yang akan diuji cobakan terdiri dari 10 peserta didik.

Selanjutnya dicoba mengelompokkan data diatas menjadi 3 kelompok. Dengan menggunakan algoritma Kmeans, berikut langkah-langkah penyelesaiannya:

1. Menentukan Jumlah cluster, jumlah cluster merupakan jumlah kelompok yan akan dihasilakan. Dalam penelitian ini jumlah cluster yang akan digunakan adalah sebanyak 3 cluster.

2. Menentukan centroid awal, centroid awal diperoleh secara acak. Centroid awal merupakan titik pusat cluster pertama. Centroid awal dari penelitian ini adalah : $\mathrm{C} 1=(4,83.00,80.08,87.67,2,75)$ $\mathrm{C} 5=(1,86.67,84.33,93.67,2,65)$ $\mathrm{C} 10=(3,83.67,90.07,70.97,1,78)$

Tabel 1. Data Peserta Didik SMK YAPIM

\begin{tabular}{cccccccc}
\hline No & $\begin{array}{c}\text { Kode } \\
\text { Siswa }\end{array}$ & $\begin{array}{c}\text { Ekstra- } \\
\text { kulikuler }\end{array}$ & Tugas & UTS & UAS & Absen & $\begin{array}{c}\text { Nilai } \\
\text { Sikap }\end{array}$ \\
\hline 1 & AAA & 4 & 83.00 & 80.08 & 87.67 & 2 & 75 \\
\hline 2 & BBB & 2 & 80.67 & 83.33 & 88.00 & 0 & 65 \\
\hline 3 & CCC & 2 & 83.67 & 85.67 & 82.33 & 1 & 85 \\
\hline 4 & DDD & 1 & 76.67 & 86.33 & 86.67 & 1 & 75 \\
\hline 5 & EEE & 1 & 86.67 & 84.33 & 93.67 & 2 & 65 \\
\hline 6 & FFF & 0 & 87.67 & 80.00 & 87.00 & 0 & 86 \\
\hline 7 & GGG & 1 & 83.33 & 80.67 & 80.67 & 0 & 77 \\
\hline 8 & HHH & 2 & 85.67 & 83.67 & 76.67 & 1 & 66 \\
\hline 9 & III & 1 & 86.33 & 76.67 & 86.67 & 0 & 88 \\
\hline 10 & JJJ & 3 & 83.67 & 90.07 & 70.97 & 1 & 78 \\
\hline
\end{tabular}


3. Menghitung jarak setiap data yang ada terhadap setiap pusat cluster. Berikut perhitungannya dengan menggunakan persamaan Euclidean Distance Space:

a. Jarak antara data siswa pertama dengan pusat cluster pertama.

C1 $\sqrt{\begin{array}{l}(4-4)^{2}+(83.00-83.00)^{2}+(80.08-80.08)^{2} \\ +(87.67-87.67)^{2}+(2-2)^{2}+(75-75)^{2}=0\end{array}}$

b. Jarak antara data siswa pertama dengan pusat cluster ke dua

C2 $\sqrt{(1-4)^{2}+(86.67-83.00)^{2}+(84.33-80.08)^{2}}$

c. Jarak antara data siswa pertama dengan pusat cluster ke tiga c3 $\sqrt{\begin{array}{c}(3-4)^{2}+(83.67-83.00)^{2}+(90.07-80.08)^{2} \\ +(70.97-87.67)^{2}+(1-2)^{2}+(78-75)^{2}=19.75\end{array}}$

Adapun hasil dari perhitungan dari keseluruan data terhadap tiap pusat cluster awal disajikan pada tabel 2 .

Tabel 2. Hasil Perhitungan Jarak Data Siswa pada Masing-Masing Centroid.

\begin{tabular}{ccc}
\hline C1 & C2 & C3 \\
\hline 0 & 13.29 & 19.75 \\
\hline 11.14 & 8.61 & 22.70 \\
\hline 12.85 & 23.27 & 14.09 \\
\hline 9.49 & 15.94 & 17.96 \\
\hline 13.29 & 0 & 27.04 \\
\hline 12.78 & 22.59 & 21.17 \\
\hline 8.15 & 18.48 & 13.73 \\
\hline 15.07 & 17.13 & 14.91 \\
\hline 14.34 & 25.31 & 23.20 \\
\hline 19.75 & 27.04 & 0
\end{tabular}

4. Pengelompokan data cluster, setelah perhitungan jarak data pada centroid, langkah selanjutnya adalah pengelompokkan data. Berikut adalah hasil pengelompokannya.

Perhitungan dapat dilakukan secara manual dengan menggunakan microsoft excel maksud dari angka 2 adalah menunjukan daerah yang paling sedikit mendapatkan prestasi, angka 1 menunjukan daerah yang sedang, dan angka 0 menunjukan daerah yang paling sering mendapatkan prestasi.

Tabel 3. Hasil Pengelompokan Data.

\begin{tabular}{cccccc}
\hline C1 & C2 & C3 & C1 & C2 & C3 \\
\hline 0 & 13.29 & 19.75 & 2 & 1 & 0 \\
\hline 11.14 & 8.61 & 22.70 & 1 & 2 & 0 \\
\hline 12.85 & 23.27 & 14.09 & 2 & 0 & 1 \\
\hline 9.49 & 15.94 & 17.96 & 2 & 1 & 0 \\
\hline 13.29 & 0 & 27.04 & 1 & 2 & 0 \\
\hline 12.78 & 22.59 & 21.17 & 2 & 0 & 1 \\
\hline 8.15 & 18.48 & 13.73 & 2 & 0 & 1 \\
\hline 15.07 & 17.13 & 14.91 & 1 & 0 & 2 \\
\hline 14.34 & 25.31 & 23.20 & 2 & 0 & 1 \\
\hline 19.75 & 27.04 & 0 & 1 & 0 & 2 \\
\hline
\end{tabular}

5. Setelah semua data ditempatkan kedalam cluster yang terdekat, kemudian hitung kembali pusat cluster yang baru berdasarkan ratarata anggota ada pada cluster tersebut.

\begin{tabular}{rrr}
\multicolumn{3}{c}{ Tabel 4. Centroid Baru } \\
\hline C1 & C2 & C3 \\
\hline 1.50 & 1.50 & 2.50 \\
\hline 83.45 & 83.67 & 84.67 \\
\hline 81.57 & 83.83 & 86.87 \\
\hline 85.17 & 90.84 & 73.82 \\
\hline 0.67 & 1.00 & 1.00 \\
\hline 81.00 & 65.00 & 72.00 \\
\hline
\end{tabular}

Setelah didapat titik pusat baru dari tiap cluster, hitung kembali data dengan pusat cluster yang baruulangi sampai didapat pola terakhir yang sudah tidak berpindah, dalam penelitian ini. Data dihitung ualng sampai iterasi ke 3 , dimana satiap cluster tidak berubah lagi dan tidak ada lagi data yang berpindah dari satu cluster ke cluster lainnya. 
Available online at http://jurnal.stmikroyal.ac.id/index.php/jurteksi

6. Menghitung jarak data ke centroid yang baru untuk iterasi berikutnya. Dengan menggunakan nilai centroid yang baru, jarak ke masing-masing centroid dihitung sampai group baru sama dengan group lama atau group sebelumnya.

7. Menghitung jarak data ke centroid yang baru untuk iterasi berikutnya. Dengan menggunakan nilai centroid yang baru, jarak ke masing-masing centroid dihitung sampai group baru sama dengan group lama atau group sebelumnya.

Tabel 5. Hasil dan Pola Terakhir Jarak Antara Centroid dan Pusat Cluster

\begin{tabular}{cccccc}
\hline C1 & C2 & C3 & C1 & C2 & C3 \\
\hline 2 & 1 & 0 & 2 & 1 & 0 \\
\hline 1 & 2 & 0 & 1 & 2 & 0 \\
\hline 2 & 0 & 1 & 2 & 0 & 1 \\
\hline 2 & 1 & 0 & 2 & 1 & 0 \\
\hline 1 & 2 & 0 & 1 & 2 & 0 \\
\hline 2 & 0 & 1 & 2 & 0 & 1 \\
\hline 2 & 0 & 1 & 2 & 0 & 1 \\
\hline 0 & 1 & 2 & 0 & 1 & 2 \\
\hline 2 & 0 & 1 & 2 & 0 & 1 \\
\hline 1 & 0 & 2 & 1 & 0 & 2 \\
\hline
\end{tabular}

Data yang dikelompokan pada cluster 1 berjumlah 6 orang, di cluster 2 berjumlah 2 orang, dan di cluster 3 berjumlah 2 orang.Jika hasil antara iterasi sudah sama dengan iterasi sebelumnya, maka dapat dikatakan hasil penelitian telah selesai.

8. Pengujian dengan aplikasi yang telah ditentukan. Hasil dari analisis diuji lagi dengan menggunakan Rapid Miner yang sudah ada. Dengan memasukkan data hasil analisis ke Rapid Miner. Pada Text View maka akan menampilkan cluster model. Cluster model yang diperoleh dari hasil pengujian terhadap data menggunakan k-means clustering terlihat pada gambar 1 .

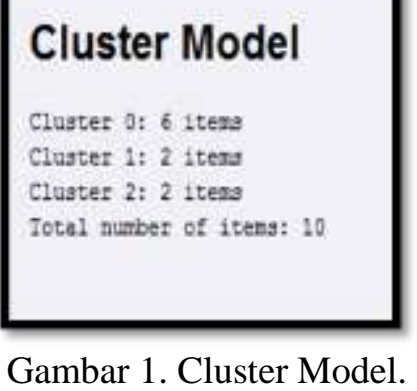

Dapat dilihat cluster model yang dihasilkan terdiri dari cluster 0 yaitu 6 items, cluster 1 terdiri dari 2 items, dan cluster 2 terdiri dari 2 items. Dari total jumlah 10 items. Dalam bentuk root memiliki 3 cluster yaitu folder cluster 0 , cluster 1 dan cluster 2. Untuk memudahkan melihat anggota yang dimiliki oleh setiap folder cluster, lihat gambar 2 yang menampilakan membership dari masing-masing cluster membership.

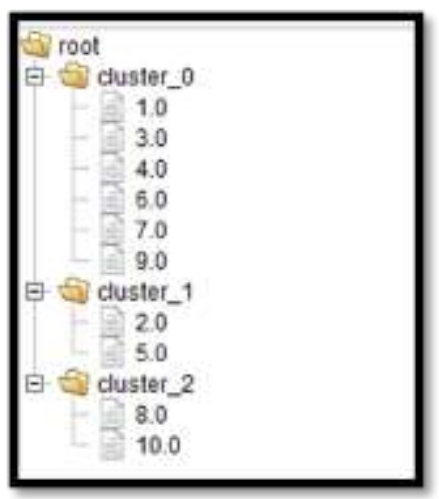

Gambar 2. Tampilan Member Masing-Masing Cluster

Untuk melihat cluster mana yang paling tinggi bisa dilihat dari gambar 3:

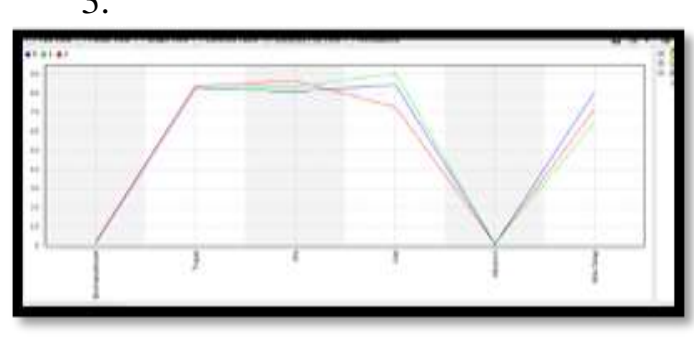

Gambar 3. Diagram Penggambaran Cluster. 
Available online at http://jurnal.stmikroyal.ac.id/index.php/jurteksi

\section{SIMPULAN}

1. Dengan menggunakan Metode Algoritma K-Means Clustering, dapat mementukan pengelompokan prestasi siswa tinggi, menengah dan cukup.

2. Dengan menginput data yang digunakan dalam penelitian ini yaitu berapa kegiatan ekstrakulikuler yang diikuti, Nilai dari Tugas, UTS, UAS, Absensi dan Nilai sikap. Output

\section{DAFTAR PUSTAKA}

Kusrini. (2007). Konsep Dan Aplikasi Sistem Pendukung Keputusan. Yogyakarta: Andi

Kusuma, S. \& Purnomo, H. (2006). Aplikasi Logika Fuzzy untuk ditampilkan dari data yang digunakan yaitu berupa pengelompokkan data berdasarkan algoritma K-Means.

3. Dengan adanya software Rapid Miner dalam penelitian ini maka keakuratan data akan cukup baik terhadap permasalahan yang terjadi terkait dengan prestasi siswa dengan hasil $70 \%$ dapat mengenali data pada 10 data yang digunakan sebagai sampel.

\footnotetext{
Pendukung

Keputusan.

Yogyakarta: Graha Ilmu.

Purnomo \& Kusumadewi. (2010). Aplikasi Logika Fuzzy Untuk Pendukung Keputusan. Yogyakarta: Graha Ilmu.
} 
Available online at http://jurnal.stmikroyal.ac.id/index.php/jurteksi 
Jurnal Pena Edukasi

Vol. 4 No. 2, Maret 2017
ISSN 2407-0769 e-ISSN 2549-4694 